\title{
Reform of Archival Legislation: a Scots Perspective ${ }^{1}$ \\ Hector L MacQueen
}

(2006) 26 Journal of the Society of Archivists

\section{Introduction}

First delivered as a paper to a conference considering issues of archival legislation and governance in Ireland, in the light of comparison with the experience of other countries, this article examines the Scottish perspective on such legislation. While I do not believe that Scotland can yet be held up as a model of modernity, we have been doing a deal of thinking on this topic over the last few years and I think some general points on which there would be broad consensus have emerged from that process.

\section{Scotland and Ireland compared}

It is useful to begin with some significant comparisons and contrasts between the position in Ireland, as I understand it, and that in Scotland:

- The Irish National Archives are an integral part of the Government's Department of Arts Sport and Tourism, whereas in Scotland the National Archives are an Executive Agency and an Associated Government Department. While this means that staff are still civil servants, the operation is largely free from direct Ministerial control. 
- The Irish National Archives have been associated under the Department of Arts, Sports and Tourism with cultural institutions such as the National Library and the National Museum. In Scotland, the Archives are closely associated with government, court and official records, rather than with culture as such. National Museums, Galleries and Libraries and the rest have always had quite separate legislative bases and different governance structures. ${ }^{2}$ In this context, the removal by the Cultural Institutions Act 1997 of the Irish Library and Museum from the Department with effect from 1 January 2005 is entirely consistent with the Scottish model.

- Our National Archives are increasingly recognising their cultural role, as not merely depositaries, but also disseminators, of material of historical, genealogical, social and political interest at many different levels, the idea that it was primarily a cultural institution would, I think, be resisted by its staff. $^{3}$

- In Scotland, the national cultural institutions are all ultimately subject to a Board of Trustees appointed from a wide range of backgrounds, and charged with responsibility for overseeing the work of the institution under its Director, Librarian or whatever it may be. So again the model of the Cultural Institutions Act is similar to what we have already. But nothing like this exists for the National Archives: the management responsibility 
there rests with the Keeper of the Records of Scotland, who is accountable, not to Trustees, or to any Advisory Council, but to the Scottish Ministers.

- The function of the Scottish Records Advisory Council (SRAC), which was set up by the Public Records (Scotland) Act 1937, and is what is now known as a Non-Departmental Public Body (NDPB), is set out in statute: to advise, not the Keeper, but the Scottish Ministers, on matters relating to the custody, preservation, indexing and cataloguing of the records of Scotland and to act as a channel of response about services to the public. ${ }^{4}$ As the Keeper's role has expanded, so also has the SRAC extended its brief to cover, not just court and central government, but all public records in Scotland, including those of local authorities, NHS trusts, and higher education institutions. In the past, the SRAC was chaired by the Keeper, and not surprisingly tended to give him unflagging support in discussions with government. ${ }^{5}$ Since 1985 , however, the chair has been an independent person appointed by the government. ${ }^{6}$ I gather that the National Archives Advisory Council (Ireland) (NAAC) has, since its inception in 1987, likewise advised the Minister, rather than the Director of the National Archives, in the exercise of his powers under the Archives Act and on all matters affecting archives and their use by the public; and that its function has been extended to advising other Ministers on any matters affecting local and habour respectively. ${ }^{7}$ 
- In Scotland, thinking on national archives legislation has long recognised that the present structure is inadequate $;^{8}$ but it was legislative devolution, initiated in 1997 and implemented in $1999,{ }^{9}$ which made a new and modern Scottish Archives Act a serious possibility. Politically, Scottish Ministers gave much more immediate priority to a Freedom of Information Act, passed in 2002 but such a statute made clear the need for a much firmer legislative footing for the work of the public archives in which so much of the relevant records and information were held. Thus archives achieved a toehold (I hope actually more of a handhold) in the political consciousness. In Ireland too a Freedom of Information Act, passed in 1997, must have triggered realisation of a need to improve further the legal basis of record-keeping and management. ${ }^{10}$

\section{Current Scottish situation}

The Public Records (Scotland) Act 1937 is a rather brief Act providing for the care and custody of certain public records by the Keeper of the Records of Scotland and allowing the transfer of certain Scottish records from London to Edinburgh. It was this latter aspect, the 'cultural restitution' or 'repatriation' of a number of thirteenth-century records which had gone to Westminster after the Edwardian conquests of the 1290s, which apparently inspired the then 12-year old lan Hamilton to join and later become leader of the Scottish nationalist group which subsequently, at Christmas 1950, reclaimed Scotland's Stone of Destiny 
from Westminster Abbey. ${ }^{11}$ That aside, so far as concerns the governance of public records and archives, the 1937 Act is of very limited scope. For example:

- it lacks a statutory definition of 'public records';

- it applies only to the Courts and to government departments, boards of trustees, or other bodies or persons holding records which belong to Her Majesty and relate exclusively or mainly to Scotland. So, although the courts, the Scottish Parliament, the Scottish Executive and its agencies, and the NHS are covered, many other public bodies are not: for example, local authorities, NHS trusts, and universities;

- the Act imposes no obligation on any of the above organisations to manage their current records properly, and only the courts are actually required to transmit any records to the Keeper;

- there is little provision on the powers and functions of the Keeper; and

- there is no provision enabling a proper response to developments in information technology, and the consequent growing use of electronic or digital records and electronic records management systems in the public as in the private sector.

Accordingly, much of the national public records system in Scotland currently operates administratively, based on the terms of the UK Public Records Acts of 1958 and 1967 . Whilst this approach ensures that arrangements are made for the selection of records at a national level for permanent preservation as 
archives, provision for the management of current records, especially electronic ones, is still very weak.

While provision at national level leaves considerable room for improvement, there is still greater room for improvement in other parts of the Scottish public sector.

- Local authorities must make unspecified 'proper arrangements' for the preservation and management of their records, in consultation with the Keeper. ${ }^{12}$ However the absence of any sanctions to enforce this means that many authorities have not put thorough records management arrangements in place. Some do provide public archive services but standards remain very variable. This has been the subject of significant criticism from archivists' groups. ${ }^{13}$

- There is no legal obligation on any other Scottish public authorities, such as NDPBs, higher and further education institutions, police authorities, etc to manage their records or to maintain archives (although many do so anyway, to highly variable degrees of quality).

All of this results in a very incomplete and inconsistent legal provision for Scottish public records and archives. The SRAC has been drawing attention to this problem since I became a member in 1998, and indeed drew up a scheme for 
legislation in 1999-2000; and in recent years there has been significant (although by no means complete) movement by government in the direction sought by the Council.

\section{Responding to the problems}

First, there has been an administrative response, falling short, however, of fullblown archives legislation. As the Code of Practice on Records Management published under section 61 of the Scottish Freedom of Information (FOI) Act says:

Any freedom of information legislation is only as good as the quality of the records to which it provides a right of access. Such rights are of limited use if reliable records are not created in the first place, if they cannot be found when needed, or if the arrangements for their eventual archiving or destruction are inadequate. ${ }^{14}$

When the FOI Bill was being considered, it was acknowledged that existing public records legislation was insufficient to support the proposed new access rights. However, it would not have been acceptable to delay the FOI legislation until new public records legislation was in place. Instead, section 61 of the Act required the Scottish Ministers to publish a Code of Practice 'providing guidance to Scottish public authorities as to the practice which it would.... be desirable for them to follow in connection with the keeping management and destruction' of 
their records. The final version of the Code was published in November 2003, along with a Model Action Plan providing detailed practical guidance. This goes some way towards addressing deficiencies in records management legislation but as it does not have any statutory force, it can never be more than a partial solution. ${ }^{15}$

\section{The Scottish Public Records Strategy}

In recognition of the concerns about the existing legislation and in response to these recent developments, the Scottish Executive announced the start of work on a Scottish Public Records Strategy in October 2003. The Strategy is examining existing legislation, guidance, standards and practices relating to Scottish public records and archives, together with the roles and functions of the key stakeholders in relation to those records, and considering whether these need to be amended or updated..$^{16}$ A public consultation paper is due to be issued before the end of 2004.

In addition to addressing the issues discussed earlier, the objectives of the Strategy are to set out measures necessary for managing Scottish public records in the twenty-first century, ensuring that the appropriate records are kept, maintained, preserved and accessible to the public. It aims to cover the full spectrum of issues surrounding Scottish public records, from the creation of modern electronic data to the permanent preservation of historical archives. 
The Strategy will include outline proposals for:

- a Public Records Bill;

- a list of Scottish public authorities to whom the Strategy will apply;

- guidance and standards to improve the quality and consistency of records management and archives;

- enforcement measures;

- the role and functions of the Keeper of the Records, the National Archives of Scotland, the Scottish Records Advisory Council, etc;

- recordkeeping by Scottish public authorities and other relevant bodies;

- a statutory definition of 'public records';

- the management of non-paper records, in particular digital records;

- the promotion and improvement of access to archives;

An important part of the Strategy is to involve a wide range of interested parties, including representatives from Scottish public authorities, records managers and archivists, and the users of records. Accordingly, the first stage of developing the Strategy was a series of seven 'stakeholder' workshops held between November 2003 and February $2004 .{ }^{17}$ These discussed a wide range of issues surrounding the management of archives and records, including:

- what public records are and why we keep them,

- which Scottish public authorities should be covered by any future legislation, 
- what aspects of record-keeping should be legislated for,

- what standards and guidance might be required,

- how requirements could be enforced and by whom, and

- the future of relevant institutions such as the National Archives of Scotland, and the Scottish Records Advisory Council.

The Strategy has also been discussed at recent meetings of the SRAC and the Scottish Council on Archives, a free-standing body set up without any external funding by archivists themselves some years ago. ${ }^{18}$ The results of these workshops and meetings have been used to form the basis of the proposals in a consultation paper which will be published before the end of 2004 by the Scottish Executive. Responses to the consultation will be used to develop the final Scottish Public Records Strategy. Those parts of the Strategy which require legislation will have to wait until a slot becomes available in the Scottish Parliament's legislative programme. However, the Strategy will also include nonstatutory measures which can be implemented in the meantime, and the Executive is aiming to start doing this in the second half of 2005.

\section{Public Record Strategy issues}

What seems likely to emerge from all this consultation and discussion by way of governance for public records and archives $?^{19}$ There is a general consensus that all Scottish public authorities should be subject to a statutory obligation to carry 
out 'effective and efficient records management'. Primary legislation should impose on Scottish public authorities general statutory requirements to:

- create, manage, store, preserve and properly dispose of their records;

- keep track of their records, including any transmission, lending, destruction, etc;

- prepare and publish indices, lists, guides, calendars and summaries of their records;

- review their records and make provision for archiving those records which merit permanent preservation;

- provide public access to their archives;

- consult the appropriate body or office-holder before destroying any records.

These general statutory requirements should be supported by sector-specific codes of practice or guidance setting out in detail how these requirements should be met. Such codes or guidance should be enforceable in the same way as the over-arching legislation.

But there is implicit in all this, a need to consider more than just efficient and effective management of the public archive. What should members of the public be entitled to expect from such archives, in terms not only of freedom of information, but also of the other uses - historical, cultural, genealogical - to 
which the public may wish to put the material? Access has to be considered in all its aspects: for example, physical location and condition (especially in relation to disability discrimination laws), cataloguing and indexing, and online facilities. There is also the danger of providing useless access, such as putting information on a website without a search facility or facilities for blind users.

How, if at all, should these duties be enforced? Many (but not all) of the participants in the Executive's workshops thought the obligations/standards must be enforceable and 'have teeth'. During the discussions, three separate 'enforcement' tasks emerged:

- production of codes of practice or guidance;

- promotion of good records management / archive practices;

- monitoring / enforcement of statutory requirements and the codes/guidance.

The task of promoting compliance with - or, perhaps better, embedding a culture of - good records management / archive practices and standards should be seen as prime, with enforcement a last resort. There should be a mix of the proactive - auditing, inspecting - with the reactive - responding to complaints. And there is room for carrots as well as sticks, perhaps with a system for official recognition and publicity for the achievement of standards and model practice levels. But the general consensus (perhaps not surprisingly) was that financial penalties would 
not be an appropriate sanction, as fining a public authority ultimately just takes money from local tax-payers, and there will be the danger of authorities taking a 'risk management' approach if legislation is too complex - that is, seeing it as easier and cheaper to ignore compliance altogether and face penalties instead. Naming and shaming would usually be more effective.

There was, however, no clear agreement on whether all these tasks should be the responsibility of one body or office-holder or split between two or more. Within the existing structure there are a number of candidates for the jobs:

First, the Keeper of the Records of Scotland / National Archives of Scotland (NAS). While the Executive workshops generally agreed that the Keeper should retain his current role (and title) as Scotland's national archivist, and also continue to provide expert advice to Scottish public authorities on records and archives issues, supported in these roles by the NAS, there was less certainty about giving him any of the other enforcement roles. The quis custodiet question inevitably arose: national organisations must meet national / international standards themselves if they are to act as role models and enforcers for the rest of the public sector. There were also some concerns that they would take too 'centralist' an approach, seeking to impose central government practices on the rest of the Scottish public sector. But the general view was that the Keeper should be entrusted with the preparation of codes of practice and guidance, and with the promotion of good management practice. The disadvantages already 
mentioned could be offset in this context by requirements of consultation and oversight by bodies representing wider interests, including those of the public.

More hesitation was apparent over the idea of the Keeper as the ultimate enforcer, perhaps reflecting the point at which the quis custodiet and centralist concerns became real for workshop participants. Such a role would transform, rather than just develop, the Keeper's present job, with one implication being that there might be a need for the Keeper to be independent of the Executive (i.e., a Parliamentary appointee) and / or for the NAS to be established as a NDPB rather than an Executive Agency, as at present.

Might some of the anxieties about the Keeper as enforcer be met by assigning that role to the Scottish Information Commissioner? After all, he is independent, and currently responsible for promoting compliance with the Code of Practice on Records Management under section 61 of the FOI Act. Accordingly, many in the workshops thought it would be a logical, and relatively small, extension of the Commissioner's powers if he were to be made responsible for enforcing and monitoring compliance with public records legislation and the codes and guidance there under. However, the concern here was the Commissioner's relative lack of archival experience or expertise, at least as presently constituted; and it is not clear that he would welcome such an extension of his present functions. Additional staff with records management and archives expertise 
would have to be appointed to this Office if the task of archive standards enforcement was also included in his portfolio.

Finally, the Scottish Records Advisory Council - as you will recall, a statutory NDPB set up in 1937. It was generally accepted in the Executive workshops that the present statutory functions of the SRAC were outdated and did not reflect current circumstances and needs, or what the SRAC actually does. It was agreed, however, that there was a need for the Scottish Ministers and the Keeper to have a source of independent expert advice and for a body to represent the interests and views of the archive community and the public interest. In this context, a key strength of the SRAC is that it represents a very wide range of interests (although this results from the appointments made by Ministers - acting often, it should be said, with advice - rather than from any provision in the 1937 Act as to what the membership should be). There was a feeling in the workshops that the broad range of expertise on the SRAC is under-utilised in the present set-up. Therefore, some argued, the SRAC should be reconstituted, with its role extended to promote and enforce public records legislation and the codes and guidance. Perhaps even going so far as to become a management board for the NAS as well, akin to the Boards of Trustees in the National Library, Museums and Galleries.

In the workshops, there was also some support for the SRAC to be given functions similar to those of the Scottish Museums Council (SMC). ${ }^{20}$ The SMC is 
a membership organisation for local (rather than national) museums and galleries in Scotland, with the aim of improving museum and gallery provision for both local people and visitors. Funded by subscriptions and grants, and with a staff complement, it fulfils many of the functions of a national agency, although not formally a NDPB. It has been recognised by Ministers in Parliament as the main adviser to the Scottish Executive and the main channel for Scottish Executive funding to non-national museums. Might a Scottish Archives Council, perhaps relating primarily to local rather than the National Archives, perform a similar role, representing and promoting the archives community, and providing support (including finance) for the development of archives? Moreover, the SMC hopes that it may be about to assume an even greater role as a result of the Cultural Review currently under way in the Scottish Executive. ${ }^{21}$ It might be that it will become like the Scottish Libraries and Information Council (SLIC), the advisory body to the Secretary of State and Scottish Ministers on library and information matters. ${ }^{22}$ SLIC is another membership organization, drawing support from across the library and information sector and funded by subscriptions but, importantly, the Scottish Executive also partially funds aspects of SLIC's work, in particular the support of local public library and information services. Might an a Scottish Archives Council usefully develop in a similar way?

There is some attraction in such models, especially in the way they bring the local as distinct from the national institution much more into the spotlight as a matter for general public concern and attention. The present Scottish Council on 
Archives could be developed to fit this role in particular. The difficulties in the case of archives are, however, readily apparent: what about the national body in this regime, and what about the public interest if we create another 'membership' body for archives, with the potential to represent primarily the interests of archivists, as distinct from those of the archive-using public? I have no doubts that archivists in general are very sensitive to the public interest in their work but it seems unfortunate that the SRAC's strength as a forum in which users have a direct, statutorily empowered, voice in advising, not only archivists, but also, crucially, Ministers, is not reflected in the SMC or SLIC models (where it depends, ultimately, on Ministers' discretion as to whether advice is even sought, and support can be cut off at any time).

As was also pointed out in the Executive workshops, while traditionally in archives public interest starts when records are 'historical', freedom of information necessarily involves a shift towards current material which transforms the picture by comparison, not only with the past of archives governance, but also with the very different public role played by museums, galleries and libraries. Freedom of information and the direct interest of government, whether central or local, mean that public records and archives are quite distinct from museums, galleries and even libraries. I very much doubt whether it is appropriate to apply the library, museums and galleries models of governance (whether national or local) to what are public authorities' records, developed first for the authority's 
purposes and only secondarily (if importantly) having a wider cultural significance. $^{23}$

In 1999, the SRAC itself recommended that it should be replaced in any new archival scheme of things by a Scottish Archives Council. ${ }^{24}$ It did not, however, see this as a self-supporting membership body like SMC and SLIC. Instead, what was proposed was a body to monitor in the public interest the activities of a much-enhanced Keeper of the Records of Scotland; to be, as we put it, 'a counterpoise to the power of the Keeper'.

We had proposed a Keeper, supported by the National Archives, regulating and advising on record-keeping by public bodies, with power to impose sanctions for non-compliance with legislatively imposed standards. We also saw the Keeper as selecting records for retention in the archive, or for destruction, as the case might be; determining whether records should be kept nationally or locally; and supporting the acquisition or acceptance for the nation of private records of national interest. ${ }^{25}$ Political control by the Ministers of the day would not be possible or appropriate beyond very general levels. We thought therefore that there was a need for a Scottish Archives Council, advising Ministers in the same way as the old SRAC, but with a much expanded remit and role. Thus its functions would include, inter alia; 
- Recommendation and promotion of policy on the whole range of archival issues (not just custody, preservation, indexing and cataloguing, as at present)

- Taking into account the interests of users, archivists and creators of records

- Reviewing the statutory activities of the Keeper

- Arbitrating in disputes regarding custody of records, standards of care, access, and so on, for which function the Keeper would be inappropriate since he might often be a party to such disputes

- Power to receive and disburse funds (e.g. award grants towards the improvement of archival services)

- Recognising the achievement of standards of care and practice by archives local and national

We were well aware that to do this resources, financial and human, were required. The membership would have to be representative of users and creators of public records, but receive appropriate professional input (possibly nominated by professional associations of archivists, but forming only a relatively 
small minority of the total membership). The lay majority would ensure the appropriate degree of independence from the archivist interest. The fact that the non-archivist element would be appointed by Ministers would further ensure that element's own ability to represent the public interest. There should also be, at least, sufficient funding to enable the Council to employ a full-time, appropriately qualified officer or administrator, to support members in carrying out their functions.

Something like this can be found in the recent archives legislation of several places, many of the Australian states ${ }^{26}$ and South Africa, ${ }^{27}$ for example. In New Zealand, a new Public Records Act has replaced an Act of 1957, and this provides for an Archives Council, to provide independent advice to the Minister on Archives New Zealand and on archives and record-keeping. ${ }^{28}$ In England and Wales the Advisory Council on National Records and Archives was created in 2003 to advise the Lord Chancellor on requests for the extended closure of public records, or from departments who want to keep records. It also looks at the corporate plan of The National Archives and how far it is meeting its targets; the acceptance of historic papers instead of tax; the sale of documents; public services provided by British archives; and at how archives care for records and papers and the level of fees. ${ }^{29}$ There was no suggestion in the 2003 consultation on new archives legislation for England and Wales that this body should be abandoned or changed..$^{30}$ 
It now seems unlikely, however, that anything like this or the SRAC's earlier proposal will be realised in Scotland. Funding is a basic issue for any government, and it is likely that the Scottish Executive will want to modernise the governance of records and archives without having to find new resources for the job. That is to say, as much as possible will be done within existing resources, i.e. using the Keeper and the National Archives as a general regulator and the Scottish Information Commissioner as an enforcer. The SRAC costs virtually nothing but a Scottish Archives Council of the kind previously proposed would involve the creation of a new NDPB at the very time Ministers are seeking major reductions in the numbers of quangos in Scotland, having had a first go at a bonfire thereof in 2001, and intending to have another blaze in 2006 (the SRAC is already under notice in this regard). In any event there are major difficulties in finding suitable appointees to such NDPBs. This is partly inherent in the nature of their tasks, but also arises because of the incredibly cumbersome bureaucratic procedures involved in making any such appointment in the UK.

Acknowledging all this, I am bound to say that the solution which seems presently to commend itself to the Executive, namely to disband the SRAC and instead merely to give some modest funding to the Scottish Council on Archives to enable it to become an archival equivalent to the SMC and SLIC, with the Scottish Information Commissioner taking on a limited enforcement role, is not a satisfactory one. The Council is a very valuable body, I am a member myself as chair of SRAC, but it is dominated by archivists, and while it endeavours with 
some success to attract representatives of user groups, it cannot perform the public interest role of monitoring the Keeper's exercise of his soon to be extended powers; nor could it deal truly independently with any matters of dispute and enforcement that might fall its way. Also ilts funding as a non-NDPB without any basis in statute would always be likely to make it vulnerable to stronger political and economic forces.

It is clear that many forces - the growth of government, digitisation, and freedom of information, to say nothing of such things as data protection and the evergrowing interest in family and local history - are all bringing public records and archives and their good management and governance to the forefront of public consciousness and debate. In that we need the pursuit of the highest possible standards of efficiency and effectiveness - and, I think, strong awareness of the public interest. My concern is with the best ways of identifying and promoting that public interest in Scotland and elsewhere.

\footnotetext{
${ }^{1}$ Chairman, Scottish Records Advisory Council; Professor of Private Law, University of Edinburgh. This is the lightly revised text of a lecture given in Dublin on 18 October 2004 at a conference, 'Reforming Archival Legislation', mounted jointly by the National Archive Advisory Council (Ireland) and the Society of Archivists Ireland. I am grateful to Stephen Bruce, Freedom of Information Unit, Scottish Executive, and George Mackenzie, Keeper of the Records of Scotland, for helpful discussions and information during the preparation of the paper. However I alone am responsible for what it says, and should add that the views expressed are entirely mine, and in no way represent those of the Scottish Records Advisory Council or any of its other members.

${ }^{2}$ See National Galleries of Scotland Act 1906; National Library of Scotland Act 1925; National Heritage (Scotland) Act 1985; all as subsequently amended. The current state of the law can be traced through Laws of Scotland: Stair Memorial Encyclopaedia, vol 13, 'Libraries, Museums and Galleries', and the Encyclopaedia's updating service.

${ }^{3}$ See for example the website Scottish Archive Network (SCAN). Available at $<$ http://www.scan.org.uk/> (accessed 14 July 2005).
} 
${ }^{4}$ Public Records (Scotland) Act 1937, s 7; Freedom of Information (Scotland) Act 2002, s 70, both available from <http://www.nas.gov.uk/reckeep/RLS.asp\#Info> (accessed 14 July 2005). ${ }^{5}$ See for instance Imrie, John. 'The modern Scottish Record Office.' Scottish Historical Review 53 (1974): 198-9, 201, 202, 205-6.

${ }^{6}$ National Heritage (Scotland) Act 1985, s 19(1).

${ }^{7}$ Information about the NAAC Ireland is available at $<$ http://www.nationalarchives.ie/about/naac.htm> (accessed 14 July 2005).

${ }^{8}$ Imrie, 'Scottish Record Office', 209, writing in 1974: '. . . clear [that] modern practice has largely outstripped the Public Records (Scotland) Act of 1937 and new legislation will soon be required to provide a more satisfactory basis for the preservation of records in Scotland ...'. John Imrie was then Keeper of the Records of Scotland.

${ }^{9}$ See generally the Scotland Act 1998 , available at <http://www.opsi.gov.uk/acts/acts1998/19980046.htm> (accessed 14 July 2005).

${ }^{10}$ See McDonagh, Maeve. Freedom of Information Law in Ireland. Dublin: Round Hall Sweet \& Maxwell, 1998, especially chs 3B and 20C.

${ }^{11}$ Hamilton, lan. The Taking of the Stone of Destiny. Moffat: Lochar Books, 1991: 9-12; Public Records (Scotland) Act 1937, s 4 and First Schedule and Imrie, 'Scottish Record Office', 197.

${ }^{12}$ Local Government (Scotland) Act 1994, s 53. available from $<$ http://www.nas.gov.uk/reckeep/RLS.asp\#Info> (accessed 14 July 2005).

${ }^{13}$ See for instance the reports by the Archive Services in Scotland Mapping Project Board. An Archival Account of Scotland 2000, available at $<$ http://www.archives.gla.ac.uk/hostsite/archacc.pdf > and by the Archives Task Force, MLA, Listening to the Past, Speaking to the Future. London: MLA, 2004, available at <http://www.mla.gov.uk/action/archives/atf.asp> (both accessed 14 July 2005).

${ }^{14}$ The Code is available on the Scottish Executive website, at <http://www.scotland.gov.uk/about/FCSD/MCG-NW/00018022/s61code.pdf> (accessed 14 July 2005).

${ }^{15}$ Note however that in August 2004 the Scottish Information Commissioner effected a settlement between the Sunday Times newspaper and the Scottish Courts Service under the terms of the Code of Practice on Access to Scottish Executive Information, under which the Courts Service made available for the first time information about the number of successful appeals against decisions made by every sheriff and High Court judge in Scotland. See the Commissioner's website press release, available at <http://www.itspublicknowledge.info/resources/media/pressreleases/pressrelease6.htm> (accessed 14 July 2005).

${ }^{16}$ See the Scottish Executive website, available at <http://www.scotland.gov.uk/about/LPS/LPSCPS/00018593/Introduction.aspx> (accessed 14 July 2005).

${ }_{17}$ Available at <http://www.scotland.gov.uk/about/LPS/LPS-CPS/00018593/WORKSHOPS.aspx> (accessed 14 July 2005).

${ }^{18}$ See the SRAC website, available at <http://www.nas.gov.uk/about_nas.htm > and the SCA website, available at <http://www.archives.org.uk/sca/>, (both accessed 14 July 2005).

${ }^{19}$ A note of the workshop discussions on which the following section of the paper is based, is available at <http://www.scotland.gov.uk/Resource/Doc/1066/0003813.pdf> (accessed 14 July 2005).

${ }^{20}$ Information on the SMC is available at <http://www.scottishmuseums.org.uk/> (accessed 14 July 2005).

${ }^{21}$ Available at

<http://www.scotland.gov.uk/about/ED/SACBranch1/00019347/page90851483.aspx> (accessed 14 July 2005).

${ }^{22}$ Information on the SLIC is available at <http://www.slainte.org.uk/index.htm> (accessed 14 July 2005).

${ }^{23}$ This, however, is not to say that there is no merit in looking at museums, galleries, libraries and archives as a single sector for some purposes, as with the UK Museums, Libraries and Archives Council, website available at <http://www.mla.gov.uk/index.asp> (accessed 14 July 2005). 
${ }^{24}$ a summary overview of the proposed legislation is available at

<http://www.dundee.ac.uk/archives/snal1999.htm> (accessed 14 July 2005).

${ }^{25}$ The NAS is already involved in private records and archives through its National Register of Archives, for which see Imrie, 'Scottish Record Office', 207; Murray, A. L. 'The National Register of Archives (Scotland).' Unpublished lecture to the Society of Archivists delivered in April 1986; and Rosie, Alison. 'Something sensible for a change: the National Register of Archives for Scotland.' Scottish Archivist, forthcoming. I am grateful to Drs Murray and Rosie for sight of their papers.

${ }_{26}$ For instance the Public Records Act 2002 (Queensland), establishing a Public Records Review Committee (for which see further http://www.archives.qld.gov.au/government/review.asp); Part 8 of the State Records Act 2000 (Western Australia), establishing a State Records Commission; and the State Records Act 1997 (South Australia), establishing a State Records Council, available at

<http://www.archives.sa.gov.au/management/youandstaterecordsact.html\#What_is_the_State_R ecords_Act_> (both accessed 14 July 2005).

${ }^{27}$ See the National Archives and Records Service of South Africa Act 43 of 1996, s 6 (as amended by s 11 of Act 36 of 2001), establishing a National Archives Advisory Council to advise the Minister and the Director-General of Arts and Culture on any matter relating to the operation of the Act, and the National Archivist on furthering the objects and functions of the National Archives; also to advise and consult with the South African Heritage Resources Agency on the protection of records forming part of the National Estate; to consult with the Public Protector on investigations into unauthorized destruction of records otherwise protected under the Act; and to submit a business plan annually to the Minister for his approval.

${ }^{28}$ Available at <http://www.archives.govt.nz/about/legislation.html> (accessed 14 July 2005).

${ }^{29}$ Full information available at <http://www.nationalarchives.gov.uk/advisorycouncil/> (accessed 14 July 2005).

${ }^{30}$ Available at <http://www.nationalarchives.gov.uk/policy/proposed/default.htm> (accessed 14 July 2005). 